\title{
New Drug/Vaccine RNA-Peptide Named Melody Against SARS-CoV-2: Adapting Antiviral Pathways in Cell Culture WM-266 as Temporal Memory of "In Vitro Cell"
}

Journal of Bioscience \& Biomedical Engineering

Research Article

"CRUZ-RODRIGUEZ L. ${ }^{1,2,3,4}$, ZAYAS TAMAYO A. ${ }^{1,2}$, DILSIZ N. ${ }^{5}$ and "LAMBERT BROWN D. ${ }^{1,2}$

${ }^{I}$ ELIDAN dynamic LLC, Miami, Florida, USA.

${ }^{2}$ ExCELab Co. Ltd., Environmental Biotechnology Department, Kingston, Jamaica.

${ }^{3}$ ELIDAN america LLC, Miami, FL, USA

${ }^{4}$ ELIDAN genome SAS, 1 av du Lycée, 77130 Montereau FY; France

${ }^{5}$ Molecular Biology and Genetics, Faculty of Engineering and Natural Sciences, Istanbul Medeniyet University, Istanbul, Turkey.

\author{
*Correspondence authors
}

\author{
Prof. Dr. CRUZ-RODRIGUEZ Luis \\ ELIDAN america LLC \\ Miami, FL, USA \\ Email : luis.cruzrguez@gmail.com \\ 1cr@elidan-genome.com \\ Dr. LAMBERT BROWN David \\ CEO, \\ ExCELab Co. Ltd. \\ Environmental Biotechnology Department \\ Kingston, Jamaica. \\ Email : dalamja1@gmail.com
}

Submitted : 30 Mar Jan 2021 ; Published : 19 Apr 2021

\begin{abstract}
The new coronavirus formed a clade within the subgenus Orthocoronavirinae, sarbecovirus subfamily. The first time these cases were published, and they were classified as "pneumonia of unknown etiology." The Chinese Center for Disease Control and Prevention (CDC) and local CDCs organized an intensive outbreak investigation program. The etiology of this illness is now attributed to a novel virus belonging to the coronavirus (CoV) family, COVID-19. This disease has inflicted catastrophic damages in public health, economic and social stability-putting life globally on hold in 2020 and presumably a year more. The authorized vaccine against severe acute respiratory syndrome coronavirus-2 (SARS-CoV-2) more often are Pfizer-BioNTech, Moderna, Johnson \& Johnson and AstraZeneca in order to face the global pandemic COVID-19. Our aim was focused on toxicological evaluation of a new drug/vaccine model against SARS-CoV-2 with therapeutic and prophylactic actions, also useful in postCOVID-19 infection rehabilitation. Our candidate of drug/vaccine RNA-peptide named Melody was tested in cell culture WM-266 as temporal memory of "In vitro cell". We carry out our studies of this RNA target Human Malignant Melanoma cell lines, (WM-266) monitoring dead cell number. The lethal concentration (LC) at 50\% and $100 \%\left(C L_{50}\right.$ and $\left.C L_{100}\right)$ were calculated and reported the toxicological and efficacity findings in each study.
\end{abstract}

Keywords: SARS-CoV-2, Exosomes, Lethal Concentration (LC), Toxicological Test, Efficacity.

Historical overview and problems

Pandemics are increasingly common. Our project has suggested geological-geogenic-climactic-zoonotic connectivity's. Their elucidation and risk profiling are ancillary goals through nanotechnology research. Combined, viruses such as SARSCoV-2, HIV-1, breast/ovarian and lung cancers incur enormous, suffering, health, and nation costs. Indeed, such cost burdens are so great they inflict national dept, even recessions through social costs, evidenced recently of the likes we have seldom seen in recent history [1-3].

Nowadays, Pfizer and Moderna biopharmaceutical companies have developed two RNA vaccine to face COVID-19 pandemic [4]. A vaccine for severe acute respiratory syndrome coronavirus-2 (SARS-CoV-2) is needed to control the coronavirus disease 2019 (COVID-19) global pandemic. Structural studies have led to the development of mutations that stabilize Betacoronavirus spike proteins in the prefusion state, improving their expression and increasing immunogenicity. Moderna vaccine shows that mRNA induces potent neutralizing antibody responses and protects against SARS-CoV-2 infection in the lungs and noses of mice without evidence of immunopathology [5].

Our aim was focused on toxicological evaluation of a new drug/vaccine model against SARS-CoV-2 with therapeutic and prophylactic actions, also useful in post-COVID-19 infection rehabilitation. Our candidate of drug/vaccine RNApeptide named Melody was tested in in cell culture WM-266 as temporal memory of "In vitro cell" [6,7], which has undergone clinical investigations. 


\section{Materials and Methods}

In order to test the toxicity level of RNA-peptide (Melody) we carry out our studies of this RNA target human malignant metastatic melanoma cell line, (WM-266 purchased from American Type Culture Collection, USA) monitoring dead cell number. The cells were cultured in a $75 \mathrm{~cm}^{2}$ culture flask in minimal essential medium (MEM) supplemented with $10 \%$ of heat-inactivated fetal bovine serum (Gibco, Life Technologies, Germany) and $5 \mathrm{ml}$ of penicillin/streptomycin (10.000 units $/ \mathrm{ml})$. Cells were cultivated in an incubator $(5 \%$ $\mathrm{CO}_{2}, 37^{\circ} \mathrm{C},>95 \%$ humidity). The cells were split when they were $90 \%$ confluent. Compounds were added to the cells in MEM supplemented with fetal bovine serum (FBS) in 384well plates. The Lethal Concentration (LC) at $50 \%$ and $100 \%$ $\left(\mathrm{LC}_{50}\right.$ and $\left.\mathrm{LC}_{100}\right)$ were calculated in each study [8-10].

Study the toxicological action of control assay control assays

- Phorbol 12-myristate 13-acetate (PMA; phorbol ester) activates protein kinase $\mathrm{C}$, which then activates a wide range of signaling pathways, including ERK via effects on the upstream kinase Raf. ERK then activates a wide range of downstream targets, including S6 ribosomal protein. PMA, through its activation of PKC, can activate T-cells and stimulate low-level production of IL-2 [11-13].

- Hydrogen peroxide solution $\left(\mathrm{H}_{2} \mathrm{O}_{2}\right)$; Oxygen free radicals generated by $\mathrm{H}_{2} \mathrm{O}_{2}$ are involved in the multistage carcinogenic process; mechanisms include carcinogen activation, oxidative DNA/RNA damage, and tumor promotion. In this study, we have evaluated another potential mechanism of $\mathrm{H}_{2} \mathrm{O}_{2}$ in carcinogenesis-modulation of DNA repair activities [14].

- Phosphate-buffered saline (PBS) is a buffer solution commonly used in biological solutions. PBS has many uses because it is isotonic and non-toxic to most cells [15]

- Exosomes are a membrane bound small extracellular vesicles ( $\mathrm{sEVs}$ ), that contain cellular composite cargo of nucleic acids mainly microRNAs (miRNAs), proteins, lipid and metabolites [16-18].

- $\quad$ RNA “target [19-21].

\section{Toxicological studies}

\section{Target: RNA polyA-CUCCUAGAACUAGCAUUA- CAGAUG---- [22]}

In order to test the toxicity level of control assay we made our studies in Human malignant melanoma cell lines (WM-266) culture cell. We monitored dead cell number using flow cytometry according to the manufacturer's recommendations. The percentage of the dead cells was calculated according to the formula:

$$
\% \text { dead cell }=\frac{\text { Dead cell number }}{\text { Total cell number }} \times 100 \%
$$

We calculated $\mathrm{LC}_{50}$ and $\mathrm{LC}_{100}, \mathrm{LC}_{50}$ values are frequently used as a general indicator of a target's acute toxicity.
Flow cytometry of cell surface receptor staining (FACS): Protocol FACS

After confluency stage of the cell lines, wash the cell lines (single cell suspension) and adjust cell number to a concentration of $1-5 \times 10^{6}$ cells $/ \mathrm{ml}$ in ice cold FACS Buffer (PBS, 0.5-1\% BSA or $5-10 \% \mathrm{FBS}, 0.1 \% \mathrm{NaN}_{3}$ sodium azide).

The cell culture is usually stained in polystyrene round-bottom 12 x $75 \mathrm{~mm}$ BD polystyrene tube (cat \# Z376787). It is convenient to check the viability of the cells which should be around $95 \%$ but not less than $90 \%$.

For each cell line suspension:

- $100 \mu \mathrm{L}$ of each cell line suspension was transferred to each tube.

- $\quad 0.1-10 \mu \mathrm{g} / \mathrm{ml}$ of the primary labeled antibody was added to each tube.

- Dilutions, if necessary, was made in FACS buffer.

- Cells were incubated for at least $30 \mathrm{~min}$ at $4{ }^{\circ} \mathrm{C}$ in the dark.

- The cells were centrifuged at $1500 \mathrm{rpm}$ for 5 minutes and resuspended in $200 \mu \mathrm{L}$ of ice cold FACS buffer.

- $\quad$ The cells were incubated for at least $20-30$ minutes at $4{ }^{\circ} \mathrm{C}$ in the dark. The cells centrifuged at $1500 \mathrm{rpm}$ for 5 minutes and resuspended in $200 \mu \mathrm{L}$ to of ice cold FACS buffer. The cells were stored in the dark at $4^{\circ} \mathrm{C}$ in a fridge until analysis.

- The cells were then analyzed on the flow cytometer as soon as possible.

- We made the analysis on the same day. For extended storage (16 hours), we resuspended the five cell lines in 1-4\% paraformaldehyde to prevent deterioration.

\section{PMA Toxicological test: \% DEAD CELLS (Flow Cytom-} etry)

In order to test the toxicity level of PMA we made our studies in WM-266 culture cell. We monitored dead cell number using flow cytometry. We calculated $\mathrm{LC}_{50}$ and $\mathrm{LC}_{100}, \mathrm{LC}_{50}$ values are frequently used as a general indicator of a target's acute toxicity.

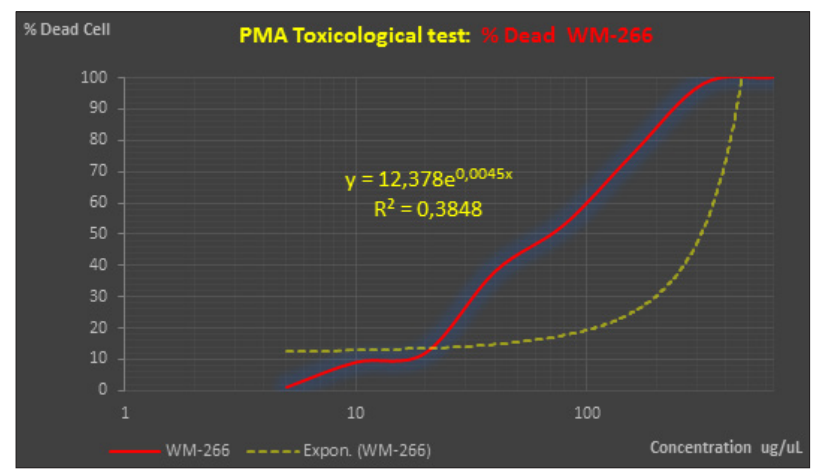

Figure 1: We are showing the PMA toxicological test in WM266 cell lines. The yellow curve represents the exponential dead cell according to serial concentration of PMA $(5 \mu \mathrm{g} / \mu \mathrm{L}$, $10 \mu \mathrm{g} / \mu \mathrm{L}, 20 \mu \mathrm{g} / \mu \mathrm{L}, 40 \mu \mathrm{g} / \mu \mathrm{L}, 80 \mu \mathrm{g} / \mu \mathrm{L}, 160 \mu \mathrm{g} / \mu \mathrm{L}, 320 \mu \mathrm{g} /$ $\mu \mathrm{L}$ and $640 \mu \mathrm{g} / \mu \mathrm{L}$. 
$\mathrm{H}_{2} \mathrm{O}_{2}$ Toxicological test: \% DEAD CELLS (Flow Cytometry)

In order to test the toxicity level of $\mathrm{H}_{2} \mathrm{O}_{2}$ we made our studies in WM-266 culture cell. We monitored dead cell number using flow cytometry. We calculated $\mathrm{LC}_{50}$ and $\mathrm{LC}_{100}, \mathrm{LC}_{50}$ values are frequently used as a general indicator of a target's acute toxicity.

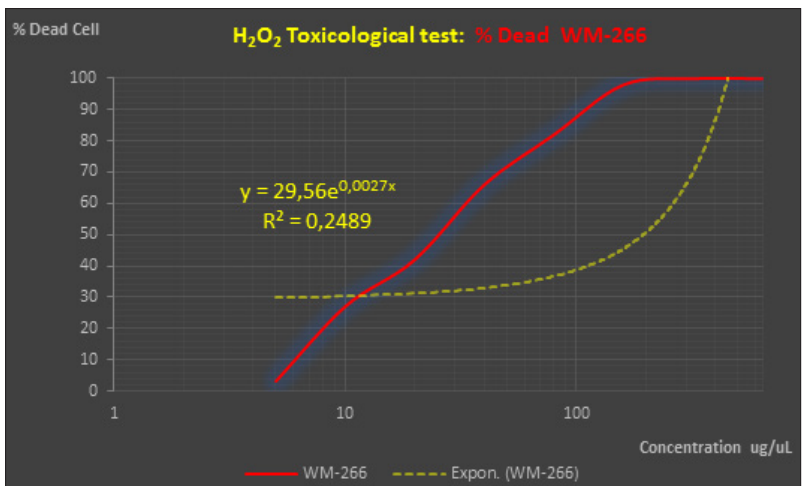

Figure 2: We are showing the $\mathrm{H}_{2} \mathrm{O}_{2}$ toxicological test in WM266 cell lines. The yellow curve represents the exponential dead cell according to serial concentration of $\mathrm{H}_{2} \mathrm{O}_{2}(5 \mu \mathrm{g} / \mu \mathrm{L}$, $10 \mu \mathrm{g} / \mu \mathrm{L}, 20 \mu \mathrm{g} / \mu \mathrm{L}, 40 \mu \mathrm{g} / \mu \mathrm{L}, 80 \mu \mathrm{g} / \mu \mathrm{L}, 160 \mu \mathrm{g} / \mu \mathrm{L}, 320 \mu \mathrm{g} /$ $\mu \mathrm{L}$ and $640 \mu \mathrm{g} / \mu \mathrm{L}$.

CuSO ${ }_{4}$ Toxicological test: \% DEAD CELLS (Flow Cytometry)

In order to test the toxicity level of $\mathrm{CuSO}_{4}$ we made our studies in WM-266 culture cell. We monitored dead cell number using flow cytometry. We calculated $\mathrm{LC}_{50}$ and $\mathrm{LC}_{100}, \mathrm{LC}_{50}$ values are frequently used as a general indicator of a target's acute toxicity.

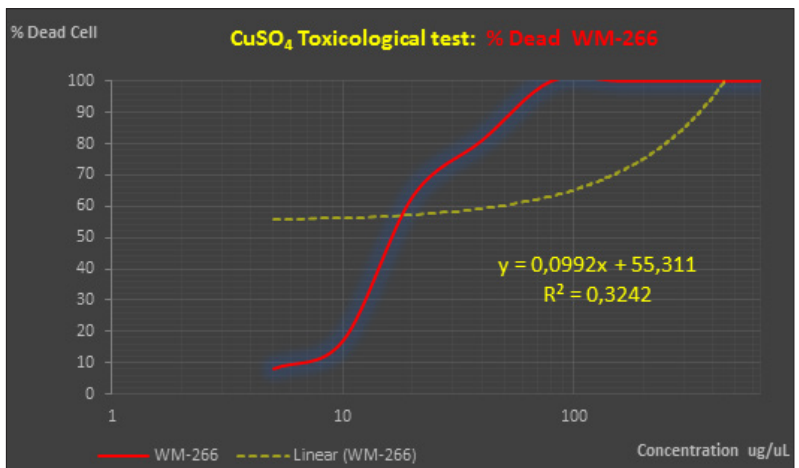

Figure 3: We are showing the $\mathrm{CuSO}_{4}$ toxicological test in WM-266 cell lines. The yellow curve represents the exponential dead cell according to serial concentration of $\mathrm{CuSO}_{4}(5 \mu \mathrm{g} /$ $\mu \mathrm{L}, 10 \mu \mathrm{g} / \mu \mathrm{L}, 20 \mu \mathrm{g} / \mu \mathrm{L}, 40 \mu \mathrm{g} / \mu \mathrm{L}, 80 \mu \mathrm{g} / \mu \mathrm{L}, 160 \mu \mathrm{g} / \mu \mathrm{L}, 320$ $\mu \mathrm{g} / \mu \mathrm{L}$ and $640 \mu \mathrm{g} / \mu \mathrm{L}$.

PBS Toxicological test: \% DEAD CELLS (Flow Cytometry)

In order to test the toxicity level of PBS we made our studies in WM-266 culture cell. We monitored dead cell number using flow cytometry. We calculated $\mathrm{LC}_{50}$ and $\mathrm{LC}_{100}, \mathrm{LC}_{50}$ values are frequently used as a general indicator of a target's acute toxicity.

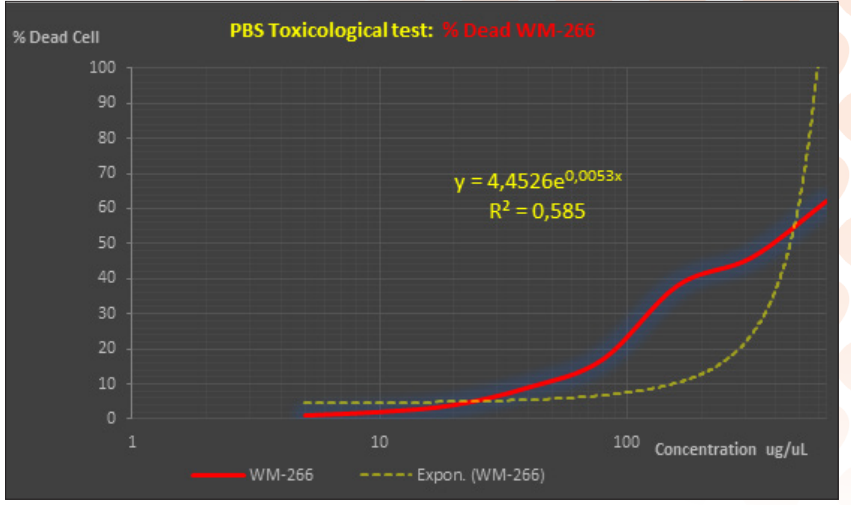

Figure 4: We are showing the PBS toxicological test in WM266 cell lines. The yellow curve represents the exponential dead cell according to serial concentration of PBS $(5 \mu \mathrm{g} / \mu \mathrm{L}$, $10 \mu \mathrm{g} / \mu \mathrm{L}, 20 \mu \mathrm{g} / \mu \mathrm{L}, 40 \mu \mathrm{g} / \mu \mathrm{L}, 80 \mu \mathrm{g} / \mu \mathrm{L}, 160 \mu \mathrm{g} / \mu \mathrm{L}, 320 \mu \mathrm{g} /$ $\mu \mathrm{L}$ and $640 \mu \mathrm{g} / \mu \mathrm{L}$.

Exosome Toxicological test: \% DEAD CELLS (Flow Cytometry)

In order to test the toxicity level of exosome we made our studies in WM-266 culture cells. We monitored dead cell number using flow cytometry. We calculated $\mathrm{LC}_{50}$ and $\mathrm{LC}_{100}, \mathrm{LC}_{50}$ values are frequently used as a general indicator of a target's acute toxicity.

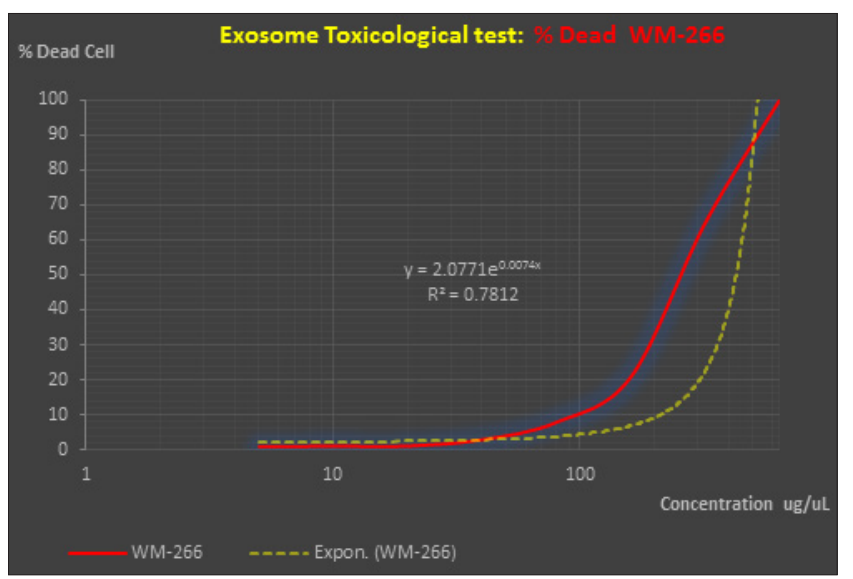

Figure 5: We are showing the exosome toxicological test in WM-266 cell lines. The yellow curve represents the exponential dead cell according to serial concentration of exosome (5 $\mu \mathrm{g} / \mu \mathrm{L}, 10 \mu \mathrm{g} / \mu \mathrm{L}, 20 \mu \mathrm{g} / \mu \mathrm{L}, 40 \mu \mathrm{g} / \mu \mathrm{L}, 80 \mu \mathrm{g} / \mu \mathrm{L}, 160 \mu \mathrm{g} / \mu \mathrm{L}$, $320 \mu \mathrm{g} / \mu \mathrm{L}$ and $640 \mu \mathrm{g} / \mu \mathrm{L}$.

\section{RNA Toxicological test: \% DEAD CELLS (Flow Cytome-} try)

In order to test the toxicity level of RNA we made our studies in WM-266 culture cell [23]. We monitored dead cell number using flow cytometry. We calculated $\mathrm{LC}_{50}$ and $\mathrm{LC}_{100}, \mathrm{LC}_{50}$ values are frequently used as a general indicator of the target's acute toxicity 


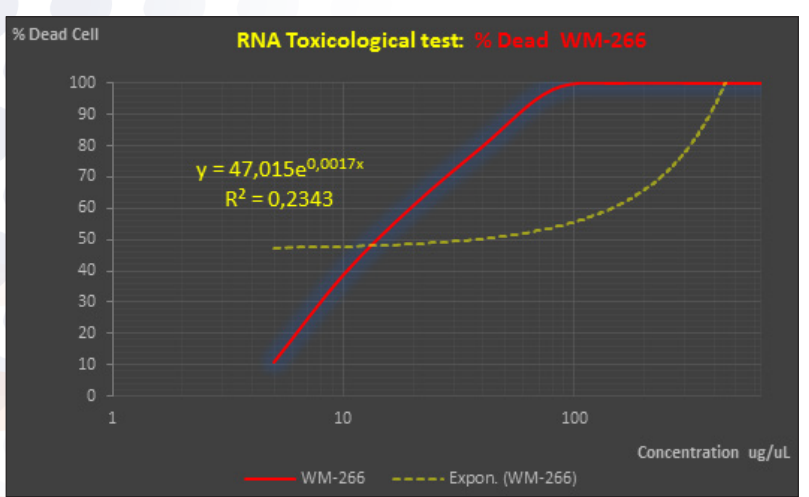

Figure 6: We are showing the RNA toxicological test in WM266 cell lines. The yellow curve represents the exponential dead cell according to serial concentration of RNA $(5 \mu \mathrm{g} / \mu \mathrm{L}$, $10 \mu \mathrm{g} / \mu \mathrm{L}, 20 \mu \mathrm{g} / \mu \mathrm{L}, 40 \mu \mathrm{g} / \mu \mathrm{L}, 80 \mu \mathrm{g} / \mu \mathrm{L}, 160 \mu \mathrm{g} / \mu \mathrm{L}, 320 \mu \mathrm{g} /$ $\mu \mathrm{L}$ and $640 \mu \mathrm{g} / \mu \mathrm{L}$

Results and discussion of toxicological test at concentrations lethal of $\mathbf{5 0 \%}$

The studies of cell proliferation action of this invention were carried out at concentrations lethal of 50\% (CL50) in WM-266 cell lines. We obtained as a result that: The present studies do not present a statistical difference in toxicity values with PMA (positive inductor of cell proliferation). Meanwhile, the invention melody presents a statistical difference with the negative controls of proliferation such as: $\mathrm{H}_{2} \mathrm{O}_{2}$ and $\mathrm{CuSO}_{4}$. Being a statistically significant difference with sulfate of copper (II).

On the other hand, we have verified that the melody invention $W M-266$ cell line a statistical difference between the toxicity values $\mathrm{CL}_{50}$ with the controls assay such as: PBS and exosomes. Finally, the melody vaccine shows in $W M-266$ cell lines a statistical difference between the toxicity values at CL50 with the test RNA target.

\section{Conclusion}

We can conclude that this invention at $\mathrm{CL}_{100}$, presents equivalents mechanisms of toxicity comparing with the inductor of cell proliferation (PMA) and $\mathrm{CuSO}_{4}$. And melody, not presents equivalents mechanisms of toxicity comparing with $\mathrm{H}_{2} \mathrm{O}_{2}$. The melody invention does not present a significant difference between the toxicity values at $\mathrm{CL}_{100}$ with the assay controls and targets [18-20].

\section{Results and discussion of toxicological test at concen-} trations lethal of $100 \%$

The studies of cell proliferation action of this invention were carried out at concentrations lethal of 100\% (CL100) in WM266 cell line. We obtained as a result that: The present invention does not present a statistical difference in toxicity values with $\mathrm{PMA}_{\text {and }} \mathrm{CuSO}_{4}$. Meanwhile, the invention melody presents a statistical difference with the $\mathrm{H}_{2} \mathrm{O}_{2}$.

On the other hand, we have verified that the melody invention shows in WM-266 a significative statistical difference in the toxicity values $\mathrm{CL}_{100}$ with the control assay PBS and not presents significant difference in the toxicity values with the exosomes.Finally, the melody invention shows in $W M-266$ a not statistical difference between the toxicity values at $\mathrm{CL}_{100}$ with target RNA.

\section{Conclusion}

We can conclude that this invention at $\mathrm{CL}_{100}$, presents equivalents mechanisms of toxicity comparing with the inductor of cell proliferation (PMA) and $\mathrm{CuSO}_{4}$. And melody, not presents equivalents mechanisms of toxicity comparing with $\mathrm{H}_{2} \mathrm{O}_{2}$. The melody invention does not present a significant difference between the toxicity values at $\mathrm{CL}_{100}$ with the assay controls and targets [18-20].

\section{Efficacity Studies of Melody}

Efficacity test one melody incubation: \% DEAD CELLS (Flow Cytometry)

In order to test the toxicity level of RNA after melody incubation 16 hours, we made our studies in the WM-266 culture cell. We monitored dead cell number using flow cytometry. We calculated $\mathrm{LC}_{50}$ and $\mathrm{LC}_{100}, \mathrm{LC}_{50}$ values are frequently used as a general indicator of a target's acute toxicity.

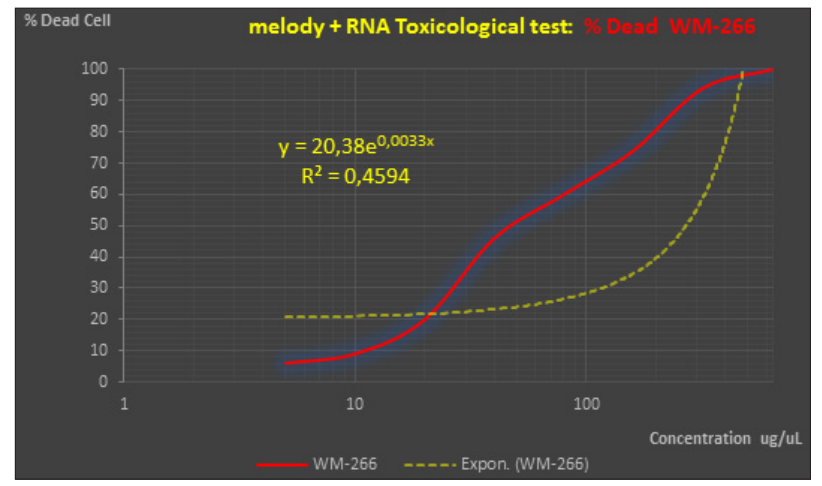

Figure 7: We are showing the RNA toxicological test in WM266 cell lines after melody incubation of 16 hours. The yellow curve represents the exponential dead cell according to serial concentration of RNA $(5 \mu \mathrm{g} / \mu \mathrm{L}, 10 \mu \mathrm{g} / \mu \mathrm{L}, 20 \mu \mathrm{g} / \mu \mathrm{L}, 40 \mu \mathrm{g} /$ $\mu \mathrm{L}, 80 \mu \mathrm{g} / \mu \mathrm{L}, 160 \mu \mathrm{g} / \mu \mathrm{L}, 320 \mu \mathrm{g} / \mu \mathrm{L}$ and $640 \mu \mathrm{g} / \mu \mathrm{L}$.

Efficacity test two melody incubations: \% DEAD CELLS (Flow Cytometry)

In order to test the toxicity level of RNA after melody incubation two times of 16 hours each incubation, we made our studies in the WM-266 culture cell. We monitored dead cell number using flow cytometry. We calculated $\mathrm{LC}_{50}$ and $\mathrm{LC}_{100}$, $\mathrm{LC}_{50}$ values are frequently used as a general indicator of a target's acute toxicity. 


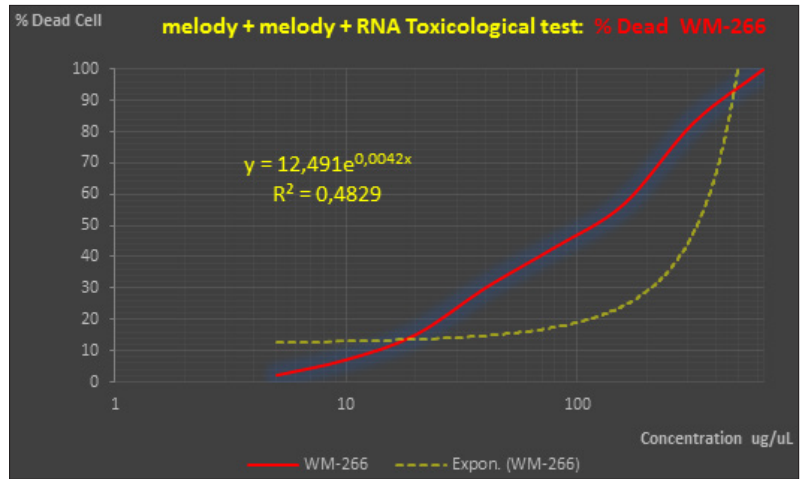

Figure 8: We are showing the RNA toxicological test in WM266 cell lines after melody incubation of 16 hours two times. The yellow curve represents the exponential dead cell according to serial concentration of RNA $(5 \mu \mathrm{g} / \mu \mathrm{L}, 10 \mu \mathrm{g} / \mu \mathrm{L}, 20 \mu \mathrm{g} /$ $\mu \mathrm{L}, 40 \mu \mathrm{g} / \mu \mathrm{L}, 80 \mu \mathrm{g} / \mu \mathrm{L}, 160 \mu \mathrm{g} / \mu \mathrm{L}, 320 \mu \mathrm{g} / \mu \mathrm{L}$ and $640 \mu \mathrm{g} /$ $\mu \mathrm{L}$.

Efficacity test three melody incubations: \% DEAD CELLS (Flow Cytometry)

In order to test the toxicity level of RNA after melody incubation three times of 16 hours each incubation, we made our studies in the WM-266 culture cell. We monitored dead cell number using flow cytometry. We calculated $\mathrm{LC}_{50}$ and $\mathrm{LC}_{100}$, $\mathrm{LC}_{50}$ values are frequently used as a general indicator of a target's acute toxicity.

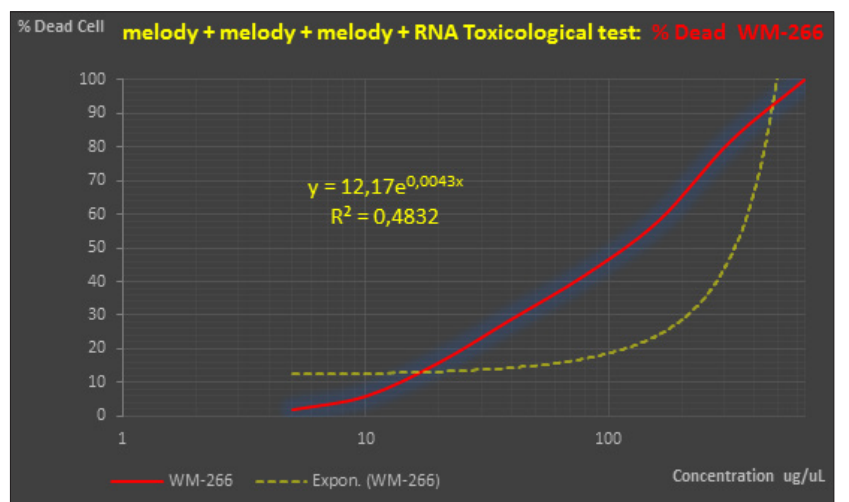

Figure 9: We are showing the RNA toxicological test in WM266 cell lines after melody incubation of 16 hours three times. The yellow curve represents the exponential dead cell according to serial concentration of RNA $(5 \mu \mathrm{g} / \mu \mathrm{L}, 10 \mu \mathrm{g} / \mu \mathrm{L}, 20 \mu \mathrm{g} /$ $\mu \mathrm{L}, 40 \mu \mathrm{g} / \mu \mathrm{L}, 80 \mu \mathrm{g} / \mu \mathrm{L}, 160 \mu \mathrm{g} / \mu \mathrm{L}, 320 \mu \mathrm{g} / \mu \mathrm{L}$ and $640 \mu \mathrm{g} /$ $\mu \mathrm{L}$.

\section{Results and discussion of efficacity test after melody} incubations at concentrations lethal of $50 \%$

The studies of melody efficacity were monitored by flux cytometry (cell viability) at concentrations lethal of $50 \%\left(\mathrm{CL}_{50}\right)$ in $W M-266$ cell line. We obtained as a result that: The cell line after melody incubation of 16 hours before treatment with RNA induced metabolic adaptation and keep this behavior in new adapting cellular pathways as "temporal memory in cell culture".

\section{Conclusion}

We can conclude that this invention at $\mathrm{CL}_{50}$ shows not equivalents mechanisms of toxicity comparing the $W M-266$ cell line incubated with melody and the same cell lines with placebo assay. We suggested that use three doses of melody can induce temporal memory in adapting pathway against RNA infection [18-20].

Results and discussion of efficacity test after melody incubations at concentrations lethal of $100 \%$

The studies of melody efficacity were monitored by flux cytometry (cell viability) at concentrations lethal of $100 \%$ (CL100) in WM-266 cell line. We obtained as a result that: The line cell after melody incubation of 16 hours before treatment with RNA induced metabolic adaptation and keep this behavior in new adapting cellular pathways as "temporal memory". The present invention shows statistical difference in the toxicity values between $W M-266$ cell line incubated with melody vaccine one or two doses and the placebo groups of cells (without melody incubation). With three doses of melody the $W M-266$ cell line and placebo not shows statistical difference in the toxicity values [24].

\section{Conclusion}

We can conclude that this invention at $\mathrm{CL}_{100}$, presents equivalents mechanisms of toxicity comparing the cell lines $W M-266$ incubated with melody and placebo assay. We suggested using two doses of melody to induce temporal memory in adapting pathway in vitro cell against RNA infection.

\section{Perspectives}

To control the coronavirus disease 2019 (COVID-19) pandemic and aid the return to pre-pandemic normalcy, vaccines are urgently required. A large number of vaccine candidates are being developed, with many of them having completed latestage clinical trials with promising results. We explore which viral components are used in COVID-19 vaccine candidates in this progress article, as well as why they may be used. In this summary, according to our results we are describing here supports the further evaluation of melody as a vaccine candidate for COVID-19. It will be key to determine this in vitro activity in the Covid-19 preclinical and clinical studies. Further studies are required to evaluate the long-term stability and immune response in animal models and the effectiveness of melody in humans [25]. 


\section{References}

1. Cruz-Rodriguez L, Dilsiz N, Barea R, Ziarati P, Hochwimmer B, Zayas Tamayo A and Lambert Brown D (2021) "The Algorithms Cruz Rodriguez (CR) are Proposing a Novel Vaccine RNA Peptide against Breast, Ovarian, and Lung Cancers Disease: Exosomes as Carrier in Cancer Progression and Metastasis". J Med-Clin Res \& Rev, 5(2): 1-16.

2. Cruz-Rodriguez L., Zayas Tamayo AM., Sanchez Batista L., Lambert Brown D., Hochwimmer B. and Ziarati P (2020) "A Novel vaccine candidate with double antiviral activity against the HIV-1 and Covid-19": International Journal of Infectious Diseases and Research, I J Infectious Disease; 2020. DOI: doi.org/10.47485/2693-2326.1002

3. Cruz-Rodriguez L., Ziarati P, Hochwimmer B., Kaabar M. K. A., Bin Zhao, N., Dilsiz N., Sanchez Batista L., Barea R., Pelaez Figueroa Y. (2020) "A DNA-Peptide Fusion as a Vaccine Candidate against Breast and Ovarian Cancer Metastasis": Consequent Benefit in Certain Lung Cancers. Journal of Bioscience \& Biomedical Engineering1 (3): 1-11. doi.org/10.47485/2693-2504.1021

4. Youdiil Ophinni, Anshari Saifuddin Hasibuan, Alvina Widhani, Suzy Maria, Sukamto Koesnoe, Evy Yunihastuti, Teguh H Karjadi, Iris Rengganis, Samsuridjal Djauzi: "COVID-19 Vaccines: Current Status and Implication for Use in Indonesia" Acta Med Indones”, 52(4): 388-412.

5. Kizzmekia S Corbett, Darin K Edwards, Sarah R Leist, Olubukola M Abiona, Seyhan Boyoglu-Barnum, Rebecca A Gillespie, Sunny Himansu, Alexandra Schäfer, Cynthia T Ziwawo, Anthony T DiPiazza, Kenneth H Dinnon, Sayda M Elbashir, Christine A Shaw, Angela Woods, Ethan J Fritch, David R Martinez, Kevin W Bock, Mahnaz Minai, Bianca M Nagata, Geoffrey B Hutchinson, Kai Wu, Carole Henry, Kapil Bahl, Dario Garcia-Dominguez, LingZhi Ma, Isabella Renzi, Wing-Pui Kong, Stephen D Schmidt, Lingshu Wang, Yi Zhang, Emily Phung, Lauren A Chang, Rebecca J Loomis, Nedim Emil Altaras, Elisabeth Narayanan, Mihir Metkar, Vlad Presnyak, Cuiping Liu, Mark K Louder, Wei Shi, Kwanyee Leung, Eun Sung Yang, Ande West, Kendra L Gully, Laura J Stevens, Nianshuang Wang, Daniel Wrapp, Nicole A Doria-Rose, Guillaume Stewart-Jones, Hamilton Bennett, Gabriela S Alvarado, Martha C Nason, Tracy J Ruckwardt, Jason S McLellan, Mark R Denison, James D Chappell, Ian N Moore, Kaitlyn M Morabito, John R Mascola, Ralph S Baric, Andrea Carfi, Barney S Graham: "SARS-CoV-2 mRNA vaccine design enabled by prototype pathogen preparedness".Nature. 586(7830): 567-571. doi: 10.1038/ s41586-020-2622-0.

6. D Krewski, M E Andersen, M G Tyshenko, K Krishnan, T Hartung, K Boekelheide, J F Wambaugh, D Jones, M Whelan, R Thomas, C Yauk, T Barton-Maclaren, I Cote "Toxicity testing in the 21st century: progress in the past decade and future perspectives"; Arch Toxicol, 94(1):1-58. doi: 10.1007/s00204-019-02613-4. Epub 2019 Dec 17.

7. R W Furlanetto, S E Harwell, R B Baggs. "Effects of insulin-like growth factor receptor inhibition on human melanomas in culture and in athymic mice". Cancer Res. 53(11): 2522-2526.
8. Qiaozhu Tan, Ming Zhang, Lujing Geng, Zhenghua Xia, Cen Li, Muhammad Usman, Yuzhi Du, Lixin Wei, Hongtao Bi." Hormesis of methylmercury-human serum albumin conjugate on N9 microglia via ERK/MAPKs and STAT3 signaling pathways". Toxicol Appl Pharmacol. 362: 59-66. doi: 10.1016/j.taap.2018.10.017.

9. Wenkang Luan, Yan Shi, Zhou Zhou, Yun Xia, Jinlong Wang."circRNA 0084043 promote malignant melanoma progression via miR-153-3p/Snail axis". Res Commun. 502(1): 22-29. doi: 10.1016/j.bbrc.2018.05.114.

10. Bei-Bei Su 1, Shu-Wei Zhou, Cai-Bin Gan, Xiao-Ning Zhang." MiR-186 inhibits cell proliferation and invasion in human cutaneous malignant melanoma" Biochem Biophys J Cancer Res Ther. 14(Supplement): S60-S64. doi: 10.4103/0973-1482.157340.

11. Rajashree Patnaik, Rabindra N Padhy.'Probit analysis of comparative assays on toxicities of lead chloride and lead acetate to in vitro cultured human umbilical cord blood lymphocytes". Interdiscip Toxicol. 8(1): 35-43. doi: 10.1515/intox-2015-0007.

12. T Chatila, L Silverman, R Miller, R Geha."Mechanisms of $\mathrm{T}$ cell activation by the calcium ionophore ionomycin" $J$ Immunol. 1989 Aug 15; 143(4):1283-1289.

13. D Galron, A Tamir, A Altman, N Isakov."Inhibition of PMA-induced human $\mathrm{T}$ cell proliferation by bryostatin is associated with enhanced degradation of conventional protein kinase $\mathrm{C}(\mathrm{cPKC})$ : $\mathrm{Ca} 2+$ signals restore mitogenic activity without abrogating enhanced cPKC degradation". Cell Immunol. 1; 158(1): 195-207. doi: 10.1006/ cimm.1994.1267.

14. J J Hu, N Dubin, D Kurland, B L Ma, G C Roush. "The effects of hydrogen peroxide on DNA repair activities". Mutat Res. 336(2): 193-201. doi: 10.1016/09218777(94)00054-a.

15. Kyle G Rodino, Mark J Espy, Seanne P Buckwalter, Robert C Walchak, Jeffery J Germer, Emily Fernholz, Aimee Boerger, Audrey N Schuetz, Joseph D Yao, Matthew J Binnicker. "J Evaluation of Saline, Phosphate-Buffered Saline, and Minimum Essential Medium as Potential Alternatives to Viral Transport Media for SARS-CoV-2 Testing”. Clin Microbiol, 58(6): e00590-20. doi: 10.1128/ JCM.00590-20.

16. Evaluation of Fusion Stability (FS), Exosome Affinity (EA) and Optimal Biological Action (OBA). U.S. Copyright number. TXu "2-229-629 Registered: 12/04/2020

17. Alex C Boomgarden, Colin Sheehan, Crislyn D'Souza-Schorey." Extracellular Vesicles in the Tumor Microenvironment: Various Implications in Tumor Progression". Adv Exp Med Biol, 1259: 155-170. doi: 10.1007/978-3030-43093-1_9.

18. Cruz-Rodriguez L, Sanchez Batista L, Hochwimmer B, Bin Zhao and Ziarati P. /2020) "The mathematical formula to estimate the Exosome Affinity between miRNA-peptide and Exosome: ALGORITHM CRUZRODRIGUEZ (EA)", Journal of Bioscience \& Biomedical Engineering, Volume 1, Issue 2, doi.org/10.47485/2693-2504.1012

19. Cruz-Rodriguez L, Cruz-Rodriguez LD, Sanchez Batista L, Hochwimmer B. (2020) "Calculation of Fusion Stabili- 
ty of [DNA or RNA] - Peptide (FS) Algorithm "Cruz-Rodriguez" Journal of Bioscience \& Biomedical Engineering, Vol 2, issue 1. doi.org/10.47485/2693-2504.1003

20. Cruz-Rodriguez L." The algorithms "CRUZ-RODRIGUEZ" (CR) as tool to design of multiepitope RNA-peptide as novel vaccine against Breast/Ovarian and Lung Cancer Diseases.

21. Thomas Kramps, Jochen Probst (2013) "Messenger RNA-based vaccines: progress, challenges, applications". Wiley Interdiscip Rev RNA., 4(6): 737-749. doi: 10.1002/ wrna.1189.

22. Cavanagh D (2007)" Coronavirus avian infectious bronchitis virus". Vet Res 38(2): 281-297. https://doi. org/10.1051/vetres:2006055

23. Tanja Prunk Zdravković, Bogdan Zdravković, Mojca Lunder, Polonca Ferk." The effect of micro-sized titanium dioxide on WM-266-4 metastatic melanoma cell line”. Bosn J Basic Med Sci.19(1): 60-66. doi: 10.17305/ bjbms.2018.3674.

24. R G M Melo, A C Leitão, M Pádula (2004) " Role of OGG1 and NTG2 in the repair of oxidative DNA damage and mutagenesis induced by hydrogen peroxide in Saccharomyces cerevisiae: relationships with transition metals iron and copper". Yeast. 21(12): 991-1003. doi: 10.1002/yea.1144.

25. Lianpan Dai, George F Gao (2021) "Viral targets for vaccines against COVID-19". Nat Rev Immunol, 21(2): 7382. doi: 10.1038/s41577-020-00480-0.

Copyright: (C2021 CRUZ-RODRIGUEZ L. This is an open-access article distributed under the terms of the Creative Commons Attribution License, which permits unrestricted use, distribution, and reproduction in anymedium, provided the original author and source are credited. 